\title{
A study to evaluate breastfeeding practices among lactating mothers: a community based study in rural anganwadi centers in field practice area of government medical college, Jabalpur, Madhya Pradesh, India
}

\section{Nisha Singh $^{1 *}$, Yogendra Chouhan ${ }^{2}$, Anshuli Trivedi $^{1}$, Seema $_{\text {Patel }}{ }^{1}$, Soumitra Sethia $^{1}$}

\author{
${ }^{1}$ Department of Community Medicine, Gandhi Medical College, Bhopal, Madhya Pradesh, India \\ ${ }^{2}$ Consultant Radiologist, Shreya Diagnostic Center, Harda, Madhya Pradesh, India
}

Received: 27 July 2016

Accepted: 31 August 2016

\section{*Correspondence:}

Dr. Nisha Singh,

E-mail: nisha.singh106@gmail.com

Copyright: (c) the author(s), publisher and licensee Medip Academy. This is an open-access article distributed under the terms of the Creative Commons Attribution Non-Commercial License, which permits unrestricted non-commercial use, distribution, and reproduction in any medium, provided the original work is properly cited.

\section{ABSTRACT}

Background: Feeding the baby exclusively on breast milk, without any other source of nutrition for a period of 6 months is called exclusive breast feeding. A child who is breast fed has greater chances of survival than a child artificially fed. The data suggests that infant mortality rates in developing countries are 5-10 times higher among children who have not been breast fed or have been breast fed for less than 6 months. Despite the marked advantages of breast feeding, its popularity has declined significantly in many parts of the world including India. The main objectives were (1) to assess breastfeeding practices prevalent amongst lactating mothers; (2) to identify misconceptions regarding failure to adopt exclusive breast feeding and weaning; (3) To counsel and motivate mothers for exclusive breastfeeding.

Methods: Mixed methods study (qualitative cum quantitative). 60 lactating mothers were interviewed and their knowledge and awareness on breast feeding was assessed through a pre-designed, semi-open questionnaire. Focused Group Discussions (FGD) were also conducted among Lactating Mothers, their Mothers or Mother in laws at Anganwadi centers of selected sites.

Results: $63.34 \%$ mothers did colostrum feeding. Only $45 \%$ of them breastfed exclusively. $48.33 \%$ gave prelacteal feeds like honey and water. LSCS was major cause of delayed initiation of breastfeeding. Many agreed regarding non supportive attitude from family. Majority of mothers had poor knowledge regarding proper positioning and attachment while breastfeeding.

Conclusions: Proper counseling and training of mothers must be done at the time of delivery by the doctors and the nursing staff regarding breastfeeding practices. Anganwadi workers must also actively counsel the mothers regarding exclusive breast feeding. Supporting women who are self-employed or who work in the informal economy is required.

Keywords: Breastfeeding practices, Anganwadi centres, Community based study

\section{INTRODUCTION}

Under any circumstances, breast milk is the ideal food for the infant. No other food is required by the baby until 6 months after birth. Feeding the baby exclusively on breast milk, without any other source of nutrition for a period of 6 months is called exclusive breast feeding. ${ }^{1} \mathrm{~A}$ child who is breast fed has greater chances of survival than a child artificially fed. The data suggests that infant mortality rates in developing countries are 5-10 times higher among children who have not been breast fed or have been breast fed for less than 6 months. ${ }^{2}$ Despite the 
marked advantages of breast feeding, its popularity has declined significantly in many parts of the world including India. NFHS-3 reveals that in India, only $46 \%$ children in age group 0-6 months are exclusively breastfed. ${ }^{3}$

Epidemiological evidences support exclusive breastfeeding as an effective intervention to advance maternal and child health. A great deal of importance has been attached to the timely initiation of breastfeeding, that is within 1 hour after birth, exclusive breastfeeding for the first 6 months of life, and continued breastfeeding until the child is at least 24 months old..$^{4-7}$

Breastfeeding benefits both the mother as well as the baby. For the baby, breast milk is highly nutritious, providing an excellent source of energy, protein, iron and vitamin A as well as antibodies and a variety of bioactive components to provide protection against disease. ${ }^{8}$

Children who are breastfed have a decreased risk of lifethreatening illnesses such as diarrhea, ear and respiratory tract infections. ${ }^{9}$ and decreased risk for chronic diseases in later life. ${ }^{10}$ If initiated soon after birth, breastfeeding helps the mothers' uterus to undergo rapid involution and reduces the risk of post-partum hemorrhage and infection. ${ }^{11}$ Other benefits include post pregnancy weight loss, decreased risk of subsequent breast and ovarian cancers and hip fractures. ${ }^{12}$

A new "baby- friendly hospital initiative" (BFHI) was created and promoted by WHO and UNICEF for encouraging proper infant feeding practices starting at birth. ${ }^{13}$ In view of the vulnerability of young infant to the risk of breast milk substitute govt. of India enacted "The infant milk substitutes, feeding bottles and infant food (Regulation of production, supply and distribution) Amendment Act 2003, was passed and came into action since $1^{\text {st }}$ January $2004 .{ }^{14}$ It prohibits the promotion of infant food, feeding bottles and milk substitutes, as promoting proper breastfeeding practices in the first 6 months of life is the most cost effective intervention for reducing childhood mortality and morbidity.

Despite the well-documented benefits of exclusive breastfeeding and initiatives taken by government to promote exclusive breastfeeding, globally it is only a relatively small proportion of infants who are fed with exclusive breastfeeding during their first 6 months. ${ }^{8,15}$ Hence, this study was conducted with the aim to find out mothers' perspective regarding exclusive breastfeeding.

\section{Objectives}

- To assess breast feeding practices prevalent amongst lactating mothers.

- To identify misconceptions regarding failure to adopt exclusive breast feeding and weaning.

- To counsel and motivate mothers for exclusive breastfeeding.

\section{METHODS}

A mixed methods study (qualitative cum quantitative) was conducted for three months (September 2010 to November 2010) to assess the breastfeeding practices prevalent amongst the rural mothers and to identify the misconceptions related to breastfeeding. Initially, permission was sought from the Head of the Department of Community Medicine, NSCB Medical College, Jabalpur for carrying out this study.

A list of Anganwadi centres which came under the field practice area of Department of Community Medicine, NSCB Medical College, Jabalpur was prepared out of which four Anganwadi centres were randomly selected which were located in Kugawan, Baidhan, Andhwa and Ghana villages in Jabalpur.

Anganwadi workers of these centers were contacted and a meeting was fixed with them. We gave them our introduction and rapport building was done by briefing them about the objectives of our study. We took the help of these anganwadi workers to collect all the nursing mothers whose babies were less than 6 months of age and those who were willing to participate, on a fixed date scheduled for interview and educational intervention. A pre- designed, semi- open questionnaire pertaining to breast feeding practices was used for collecting data.

A total of 60 Lactating Mothers who gave consent and had babies less than 6 months of age were interviewed in all the four Anganwadi Centres on separate days with an interview schedule and their knowledge and awareness on breast feeding was assessed during the interview. Those mothers who had failure of lactation were excluded from the study.

Focused Group Discussions (FGD) were also conducted with lactating mothers, their mothers or mother in laws, and Anganwadi Workers to find out the level of support system from the family and Anganwadi Center.

Health education was imparted to mothers and grandmothers highlighting the importance of exclusive breastfeeding through posters and videos and motivated them to adopt exclusive breastfeeding. Take home pamphlets were also distributed to them. Mothers were also asked to demonstrate the way they fed their babies to observe positioning and attachment.

The responses were coded logically and data collected was compiled using MS Excel 2007. The data was analyzed using epi-info 7 and is presented in the form of percentages and proportions. Chi-square test was used to find out association between breastfeeding status and selected socio demographic variables. A P value $\leq 0.05$ was considered as statistically significant. 


\section{RESULTS}

Table 1 shows that majority $(60 \%)$ of the study participants belonged to 24-29 years age group. Religion wise $80 \%$ were Hindu and $20 \%$ were Muslims. Majority of the participants $(76.67 \%)$ lived in joint families which could significantly influence the breastfeeding status. Considering education, majority $(60 \%)$ were illiterate which also plays an important role towards health awareness as educated people tends to be more aware. $88.33 \%$ mothers were working either as farmers or labourers on daily wage basis.

Table 1: Distribution of study participants according to various socio- demographic variables.

\begin{tabular}{|c|c|c|}
\hline $\begin{array}{l}\text { Socio } \\
\text { demographic } \\
\text { variables }\end{array}$ & $\begin{array}{l}\text { Number } \\
(\mathrm{n}=60)\end{array}$ & Percentage \\
\hline \multicolumn{3}{|c|}{ Age group (years) } \\
\hline $18-23$ & 21 & 35.00 \\
\hline $24-29$ & 36 & 60.00 \\
\hline$>30$ & 3 & 5.00 \\
\hline \multicolumn{3}{|l|}{ Religion } \\
\hline Hindu & 48 & 80.00 \\
\hline Muslim & 12 & 20.00 \\
\hline \multicolumn{3}{|l|}{ Type of family } \\
\hline Nuclear & 14 & 23.33 \\
\hline Joint & 46 & 76.67 \\
\hline \multicolumn{3}{|c|}{ Literacy status of mother } \\
\hline Illiterate & 36 & 60.00 \\
\hline Primary & 11 & 18.33 \\
\hline Middle & 3 & 5.00 \\
\hline High school & 7 & 11.67 \\
\hline $\begin{array}{l}\text { Higher } \\
\text { secondary }\end{array}$ & 2 & 3.33 \\
\hline $\begin{array}{l}\text { Graduation } \\
\text { and above }\end{array}$ & 1 & 1.67 \\
\hline \multicolumn{3}{|c|}{ Working status of mother } \\
\hline Working & 53 & 88.33 \\
\hline Non-working & 7 & 11.67 \\
\hline
\end{tabular}

Table 2 shows that only $63.34 \%$ mothers fed colostrums to their newborns which is quite a low percentage and is an urgent issue in a developing country like India where infant deaths due to infections are very much common. In this study, only $45 \%$ of the mothers breastfed exclusively which is quite close to the national figure of $46.8 \%$. $48.33 \%$ of mothers gave pre-lacteal feeds like honey and water, either due to lack of knowledge or under family pressures.

Only $21.67 \%$ of mothers initiated early breastfeeding within an hour after the birth of the baby, with LSCS being the major cause of delayed initiation of breastfeeding. Majority of mothers $(68.33 \%)$ had poor knowledge regarding proper positioning and attachment while breastfeeding.
Table 2: Breast feeding practices prevalent amongst study participants.

\begin{tabular}{|c|c|c|}
\hline $\begin{array}{l}\text { Breastfeeding } \\
\text { practices }\end{array}$ & $\begin{array}{l}\text { Number } \\
(n=60)\end{array}$ & Percentage \\
\hline \multicolumn{3}{|c|}{ Initiation of breastfeeding } \\
\hline $\begin{array}{l}\text { Within } 30 \text { min } \\
\text { to } 1 \text { hour after } \\
\text { birth }\end{array}$ & 13 & 21.67 \\
\hline $\begin{array}{l}\text { Within } 24 \text { hours } \\
\text { of birth }\end{array}$ & 32 & 53.33 \\
\hline $\begin{array}{l}\text { After } 24 \text { hours } \\
\text { of birth }\end{array}$ & 15 & 25 \\
\hline \multicolumn{3}{|l|}{ Type of feeding } \\
\hline $\begin{array}{l}\text { Exclusive breast } \\
\text { feeding }\end{array}$ & 27 & 45.00 \\
\hline Mixed feeding & 23 & 38.34 \\
\hline $\begin{array}{l}\text { Exclusive top } \\
\text { feeding }\end{array}$ & 10 & 16.67 \\
\hline \multicolumn{3}{|c|}{ Giving prelacteals } \\
\hline Yes & 29 & 48.33 \\
\hline No & 31 & 51.67 \\
\hline \multicolumn{3}{|c|}{ Feeding colostrum } \\
\hline Yes & 38 & 63.34 \\
\hline No & 22 & 36.67 \\
\hline \multicolumn{3}{|c|}{ Do burping after feeding } \\
\hline Yes & 52 & 86.67 \\
\hline No & 8 & 13.33 \\
\hline \multicolumn{3}{|c|}{ Number of feeds per day } \\
\hline$<4$ times & 6 & 10 \\
\hline 4-8 times & 34 & 56.67 \\
\hline$>8$ times & 20 & 33.33 \\
\hline \multicolumn{3}{|c|}{ Does night feeding } \\
\hline Yes & 18 & 30 \\
\hline No & 42 & 70 \\
\hline \multicolumn{3}{|c|}{ Has knowledge about positioning and attachment } \\
\hline Yes & 19 & 31.67 \\
\hline No & 41 & 68.33 \\
\hline
\end{tabular}

Table 3 shows distribution of exclusive breastfeeding according to different variables. With regard to age group, $28.57 \%$ of respondents up to the age 25 years and $68 \%$ of respondents $>25$ years of age were exclusively breastfeeding and the difference was statistically significant $(\mathrm{P}<0.05)$. Regarding type of family $78.57 \%$ of subjects living in a nuclear family breastfed exclusively whereas only $34.78 \%$ of those living in joint families were doing exclusive breastfeeding, the difference found to be statistically significant $(\mathrm{P}<0.05)$.

With regard to literacy, $30.56 \%$ of study subjects who were illiterate were found to be exclusively breastfeeding while $66.67 \%$ of literate females breastfed exclusively and this was found to be statistically significant $(\mathrm{P}<0.05)$. Sex of the baby evolved as a significant socio- cultural factor affecting breastfeeding in this study $(\mathrm{P}<0.05)$. Out 
of those who had male babies, $68.18 \%$ were found to be exclusively breastfeeding while among those who had female babies, only $31.58 \%$ were breastfeeding exclusively. Religion, place of delivery and working status of mother did not show statistically significant association with exclusive breastfeeding.

Table 3: Distribution of study participants according to relation between exclusive breastfeeding and different variables.

\begin{tabular}{|c|c|c|c|c|c|}
\hline \multirow{2}{*}{ Variables } & \multirow{2}{*}{ Group } & \multicolumn{2}{|c|}{ Exclusive breastfeeding } & \multirow[b]{2}{*}{ Total } & \multirow{2}{*}{ Significance } \\
\hline & & Yes $(N=27)(\%)$ & No $(\mathrm{N}=33)(\%)$ & & \\
\hline \multirow{2}{*}{ Age group } & Up to 25 years & $10(28.57)$ & $25(71.43)$ & 35 & \multirow{2}{*}{$P$ value $=0.0025^{*}$} \\
\hline & $>25$ years & $17(68)$ & $8(32)$ & 25 & \\
\hline \multirow{2}{*}{ Religion } & Hindu & $20(41.67)$ & $28(58.33)$ & 48 & \multirow{2}{*}{$P$ value $=0.29$} \\
\hline & Muslim & $7(58.33)$ & $5(41.67)$ & 12 & \\
\hline \multirow{2}{*}{ Type of family } & Nuclear & $11(78.57)$ & $3(21.43)$ & 14 & \multirow{2}{*}{$\mathrm{P}$ value $=0.01 *$} \\
\hline & Joint & $16(34.78)$ & $30(65.22)$ & 46 & \\
\hline \multirow{2}{*}{ Literacy } & Illiterate & $11(30.56)$ & $25(69.44)$ & 36 & \multirow{2}{*}{$\mathrm{P}$ value $=0.005^{*}$} \\
\hline & Literate & $16(66.67)$ & $8(33.33)$ & 24 & \\
\hline \multirow{2}{*}{ Place of delivery } & Hospital & $26(45.61)$ & $31(54.39)$ & 57 & \multirow{2}{*}{$P$ value $=0.676$} \\
\hline & Home & $1(33.33)$ & $2(66.67)$ & 3 & \\
\hline \multirow{2}{*}{ Working status } & Working & $22(41.51)$ & $31(58.49)$ & 53 & \multirow{2}{*}{$P$ value $=0.275$} \\
\hline & Non- working & $5(71.43)$ & $2(28.57)$ & 7 & \\
\hline \multirow{2}{*}{ Sex of baby } & Male & $15(68.18)$ & $7(31.82)$ & 22 & \multirow{2}{*}{$P$ value $=0.006^{*}$} \\
\hline & Female & $12(31.58)$ & $26(68.42)$ & 38 & \\
\hline
\end{tabular}

\section{Findings of focussed group discussion (FGD)}

\section{Initiation of breastfeeding}

Though the mothers were well aware of the advantages of initiating breastfeeding early including feeding of colostrum to the newborn, yet only very few of them could initiate breastfeeding within an hour after the birth of the baby. Most common reason for late initiation of breast feeding in vaginal delivery was pain in perineum followed by lack of expulsion of milk or delayed expulsion which in most cases is psychological, delay in cleaning the newborn, infant not latching properly due to prematurity and inverted nipple. On the other hand, most common reason for late initiation of breast feeding in caesarean delivery was inability to take position due to anesthesia \& stitches followed by denial by parents /husband/in-laws.

"Mujhe delivery ke bad dudh nahi a raha tha, meri saas ne kaha thoda time lagta hai, fir 4-5 ghante bad dudh ane laga tab maine bacche ko dudh pilaya"(Mother 1)

"Aspatal me aya bai ne 2 ghante bad bacche ko saaf karke mujhe diya, to mai kaise use jaldi dudh pilati" (Mother 2)

"Mera bada operation hua tha, mujhe davai ka nasha tha aur dard bi ho raha tha isliye meri saas ne dusre din hi mujhe bacche ko dudh pilane diya"'(Mother 3)

\section{Knowledge about exclusive breastfeeding}

The practice of exclusive breastfeeding is also limited. Only about 45 percent children aged less than 6 months were being breast fed exclusively. Most children were fed water before the age of 6 months. Most women did not know that 80 percent of breast milk is water. The qualitative study shows that many families started feeding their child water, particularly during summer, sometimes even within two weeks of birth. Around onethird (38.34 percent) of women gave animal milk, mainly cow's milk, to the child because it is believed to be easy to digest and gives strength. Such supplementary foods were given because women and elders in the family perceived that mother's milk is not sufficient for the child after the age of 3-4 months. They reported that the child cried frequently, even soon after breastfeeding, because the child was still hungry. They even fed sugar water and dal before the age of 6 months.

"Maine apne bacche ko chauthe mah se pani pilana shuru kar diya tha, kyuki garmi ka mausam tha aur gaon ke bade buzurg kehte hain ki bacche ka gala sukhta hai, magar pani $k$ siva aur kuch bhi nahi pilaya, kewal apna dudh hi diya" (Mother 2)

"Mere bacche ko mai apna dudh to pilati hi hu, magar sirf mere dudh se uska pet nahi bharta aur vo dudh pine ke bad bi rota rehta hai, isliye maine use tisre mah se gaye ka dudh dena bi shuru kar diya jisse uska pet bhar jata hai aur vo rota nahi hai. Gaye ka dudh pachane me bi asaan hota hai" (Mother 3) 


\section{Colostrum feeding}

Around two-thirds of women (63.34 percent) fed their newborn colostrum, indicating that colostrum feeding is almost a norm in the community. They were also aware that the "yellow milk" provides immunity to the baby. However, still a larger percentage (33.34 percent) of women did not fed colostrum to their baby due to their perception that the yellow milk is bad for baby's health. Most common reason of not feeding colostrum to the baby was that it is very heavy for baby to digest followed by lack of knowledge about importance of colostrum.

"Maine apne bacche ko pehla peela gadha dudh isliye nahi pilaya kyuki meri maa ne kaha tha ki vo bache ki sehat ke liye accha nahi hota. Kisi ne peela dudh pilane ki salah nahi di" (Mother 2)

\section{Practice of prelacteal feeding}

Findings of my study show that the practice of pre-lacteal feeding is still high (48.33 percent) in rural area. The practice of pre-lacteal feeding and early breastfeeding are competing behaviors; as the women who breastfed their children within an hour of birth did not give any pre lacteal feed. Most common pre-lacteal feed was honey followed by kaadha/ghutti. Water and even tea/coffee were also used as pre lacteal feeds in some cases. The most common belief behind giving these prelacteal feeds came out to be that giving honey to the baby makes him soft spoken while kaadha/ ghutti is supposed to keep baby's digestion good. Some people from low socioeconomic status gave tea to the baby as they could not afford to buy milk.

"Sab kehte hain ki bacche ko sabse pehle shahad khilana chahiye, usse baccha meetha bolta hai aur hoshiyaar bi hota hai, isliye humne apne pote ko pehle shahad hi khilaya fir maa ka dudh pilaya" (Grandmother 1)

"Ghutti to pilana hi padti hai bacche ko janam ke samay, isse uske pet ki gandagi saaf hoti hai aur hajma bi thik rehta hai" (Grandmother 4)

\section{Duration of breastfeeding}

There was a wide range in the reported duration or planned duration of breastfeeding extending from one month up to two years or "when the baby stops by itself". The advice which first-time mothers received from health workers and female elders on optimal duration of breastfeeding was also inconsistent. Some reported being told that it "depends on the baby", one was told 18 months, and others said they had been given no advice at all.

\footnotetext{
"Meri saas ne kaha hai ki bacche ko 18 mah ki umar tak maa ka dudh pilana chahiye" (mother 3 )
}

"Maine apne pehle bacche ko 2 saal tak apna dudh pilaya tha, dusre bacche ko bi 2 saal tak hi pilanni" (Mother 4)

\section{Reasons for stopping breastfeeding}

\section{Working mothers}

Work was one of the main reasons for stopping exclusive breastfeeding before the recommended six months and for not continuing with breastfeeding for two years. Women explained that it is not convenient for them to combine breastfeeding and work, whether it was household work or working in the fields or elsewhere. Some of the mothers felt that their workplace was not an appropriate place for a young baby or for breastfeeding.

"Ghar ka kaam bi dekhna hota hai, jyada der tak bacche ko lekar nahi baith sakte. Ghar ka kaam kaun karega? Khet ke kaam me bi pati ka hath batana padta hai, vahan dhoop me bacche ko nahi le ja sakti" (Mother 5)

"Mai aur mere pati dono majduri karte hain, ghar chalane $k$ liye mujhe bi jaldi kaam par jana pada isliye bacche ka dudh cchudana pada" (Mother 1)

\section{Insufficient milk}

Another important reason given for stopping breastfeeding was insufficient breast milk. While mothers agreed that breast milk is best for the baby in the initial months, there was a general consensus that as the baby grew older, breast milk contained insufficient nutrients. They also told that as baby grows older, his/her hunger is not satisfied by breast milk alone and thus they start top feed, which most commonly consists of cow's milk.

"Baccha bada hota hai to maa ke dudh se uska pet nahi bharta. 3-4 mah ke bad use upar ka dudh bi dena padta hai" (Grandmother 2)

\section{Baby's decision}

A few mothers explained that at about the age of one year baby stopped sucking milk itself, as it had front teeth above and below and could bite food. The baby just did not want to suck.

"Jab bacche ke dant nikal ate hain to vo maa ka dudh nahi peena chahta kyuki vo dusri sari cheeze kha sakta hai. Mere bacche ne bi aisa hi kiya tha." (Mother 2)

\section{Inverted nipples}

A less common problem, inverted nipple, was also reported as a reason by mothers for stopping breastfeeding. Though it is a treatable problem without recourse to a doctor by simple traditional methods of massage etc., for some mothers, inverted nipple could lead to termination of breastfeeding. 


\section{Family experiences and influences of community elders}

Most of the mothers agreed that they were influenced by the breastfeeding experiences of their mothers and relatives, like mother-in -laws, sister-in-laws and did breastfeeding for the same time as their own mothers. Some of the mothers also reported being influenced by the advice of friends or neighbours. It was also revealed from the qualitative study that women easily adopt the practice of early breastfeeding, colostrum feeding and not to give pre-lacteal feeds when they are encouraged and supported by family members like husbands and motherin -laws.

\begin{abstract}
"Meri saas buzurg hain, unhe jyada pata hai, isliye maine hamesha unhi ka kehna mana, vo thik hi bataengi." ( Mother 2)

"Meri saas aur pati ne baache ko sahi tarike se palne me meri bahut madad ki. Unhone hi mujhe bacche ko pehla peela dudh pilane ki salah di aur sath hi ye bi samjhaya ki shuru ke 6 mah tak bacche ko kewal ma ka dudh hi dena chahiye, aur kuch bi nahi." (Mother 4)
\end{abstract}

\section{Influences of health workers}

Many women reported that the ASHA and the Anganwadi Worker (AWW) are their preferred source of information on breastfeeding and had advised them and their family members on breastfeeding. The qualitative study reveals that in villages where ASHAs and AWW have been proactive, they have been able to motivate women to adopt early breastfeeding.

"Asha behenji aur anganwadi wali behenji ne mujhe garbhavastha ke samay hi bacche ko 6 mah tak kewal apna dudh pilane ki salah di thi, aur maine unka hi kehna mana." (Mother 6)

\section{DISCUSSION}

According to NFHS-4 data, $49 \%$ of babies are breastfed within an hour after birth. In this study, $21 \%$ mothers initiated breastfeeding within an hour, $53.3 \%$ mothers within 24 hours of delivery, $25 \%$ mothers breastfed their babies after 24 hours. ${ }^{16}$ Most common reason for late initiation of breast feeding in vaginal delivery was pain in perineum followed by lack of expulsion of milk or delayed expulsion which in most cases is psychological, delay in cleaning the newborn, infant not latching properly due to prematurity and inverted nipple. On the other hand, most common reason for late initiation of breast feeding in caesarean delivery was inability to take position due to anesthesia \& stitches followed by denial by parents /husband/in-laws.

Most of mothers in this study fed colostrums to their babies (63.4\%). In other studies by Mahmood et al $84.6 \%$ of the mothers fed colostrum. ${ }^{17}$ However, we found in our study that still a larger percentage $(33.34 \%)$ of women did not fed colostrum to their baby due to their perception that it is very heavy for baby to digest.

Regarding exclusive breastfeeding, only $45 \%$ mothers did exclusive breastfeeding till 6 months, which is almost near to National average of $46.3 \%$. While, $38.34 \%$ of mothers breastfed for less than 6 months or gave mixed feeding. The study shows that many families started feeding their child water, particularly during summer, sometimes even within two weeks of birth. As reported by Aruldas $\mathrm{K}$ et al, one-third (33 percent) of women gave animal milk, mainly goat's milk, to the child because it is believed to be "light" and hence easy to digest and gives strength. ${ }^{18}$ Early initiation of supplementary foods were done by mothers in our study because they themselves and elders in the family perceived that mother's milk is not sufficient for the child after the age of 3-4 months. Aruldas $\mathrm{K}$ et al also reported that the child cried frequently, even soon after breastfeeding, because the child was still hungry and thus was given early supplementary feeds. ${ }^{18}$

Almost all mothers practiced demand type of breastfeeding. 33\% mothers breastfed for more than 8 times per day while 57\% mothers breastfed for 4-8 times per day. Pradeep C et al reported that $78 \%$ mothers breastfed for 8-10 times/day, $20.3 \%$ of them for more than 10 times/day and only $1.7 \%$ mothers for less than 8 times/day. ${ }^{19}$

In this study, $48.33 \%$ mothers gave prelacteal feeds. Saurav C et al study showed that $54.5 \%$ of newborns receive prelacteal feeds. ${ }^{20}$ As evidenced from this study, the practice of pre-lacteal feeding and early breastfeeding are competing behaviors; as the women who breastfed their children within an hour of birth did not give any pre lacteal feed. Most common pre-lacteal feed was honey followed by kaadha/ghutti. Water and even tea/coffee were also used as pre lacteal feeds in some cases. The most common belief behind giving these prelacteal feeds came out to be that giving honey to the baby makes him soft spoken while kaadha/ ghutti is supposed to keep baby's digestion good. Kulkarni RN et al reported that $77 \%$ of women who delivered at home and $50 \%$ of women who delivered in an institution gave their child pre-lacteal feeds. $^{21}$

\section{CONCLUSION}

In this study, the proportion of mothers who breastfed exclusively was found out to be $45 \%$. Age of the mother, type of family, literacy status of mother and gender of the baby was found to be significantly associated with exclusive breastfeeding.

Overall the respondents in our study were positive towards breastfeeding and were quite well-informed, while some traditional practices were being maintained, such as discarding colostrum. Our results however, need to be understood in the context of an area undergoing 
rapid socio-economic change, including increased access to education and ante-natal care. As elsewhere, our study suggests that even where there is early initiation of breastfeeding and positive attitudes towards it, achieving optimal breastfeeding practices is difficult and requires a range of interventions.

Given the well-documented benefits of breastfeeding, further efforts need to be directed towards increasing the understanding of the benefits of exclusive breastfeeding of first-time mothers, lay people and health professionals. Information and education strategies also need to target some of specific gaps in knowledge identified in this study including understanding of what exclusive breastfeeding entails and appropriate timing of the introduction of water and supplementary feeds. Reducing the non-knowledge factors is also important.

Of particular importance is working with employers and developing supportive employment policies, including looking at ways of supporting women who are selfemployed or who work in the informal economy. In a rapidly expanding economy like India, it is likely that the demand for female workforce participation will increase and mothers will have to make vital decisions about how to feed their infants while they are at work.

\section{Recommendations}

- Women's education and their exposure to mass media is very important. Proper counseling \& training of mothers must be done at the time of pregnancy and delivery by the health workers, doctors and the nursing staff regarding breastfeeding practices so that women can adopt early as well as exclusive breastfeeding.

- Reorientation of frontline health workers is required as they are poorly informed about the composition of breast milk and breastfeeding techniques. It was also observed that health workers do not have sufficient counseling aids. Providing them with counseling aids and building counseling skills on early and exclusive breastfeeding would be critical for successfully implementing exclusive breastfeeding.

- Awareness must be built amongst the family members also as they are the key facilitators and their support is important for promoting the adoption of desired practices and sustaining behavior change, as evident from our study.

- Research is also needed to identify the optimal combination of interventions to promote good breastfeeding practices, including identifying factors which facilitate or impede breastfeeding and how inhibiting factors can be addressed.

\section{ACKNOWLEDGEMENTS}

Authors extend their sincere acknowledgement towards Dr. P. K. Kasar, Professor \& Head, Department of Community Medicine, NSCB Medical College, Jabalpur for granting permission to conduct this study and also to the Anganwadi workers and the participants for their whole hearted co-operation in this study.

Funding: No funding sources

Conflict of interest: None declared

Ethical approval: The study was approved by the Institutional Ethics Committee

\section{REFERENCES}

1. Government of India. 2004. National guideline on infant and young child feeding, $<$ http://wcd.nic.in/national_guidelines.html>.

2. Mullany LC, Katz J, Li YM, Khatry SK. 2008. Breast-feeding patterns, time to initiation, and mortality risk among newborns in southern Nepal. J Nutr. 2008;138:599-603.

3. National Family Heath Survey (NFHS -3) 2005-06, Report.

4. Chien LY, Tai CJ. Effect of delivery method and timing of breastfeeding initiation on breastfeeding outcomes in Taiwan. Birth. 2007;34:123-30.

5. Okolo SN, Adewunmi YB, Okonji MC, Okolo SN, Adewunmi YB, Okonji MC. Current breastfeeding knowledge, attitude, and practices of mothers in five rural communities in the Savannah region of Nigeria. J Trop Pediatr. 1999;45:323-6.

6. Salariya EM, Easton PM, Cater JI. Duration of breast-feeding after early initiation and frequent feeding. Lancet. 1978;2:1141-3.

7. Breastfeeding. http://www.who.int/ topics/ breastfeeding/en/ webcite.

8. UNICEF: Facts for Life. 4th edition. New York: UNICEF; 2010.

9. UNICEF: Progress for Children: A child Survival Report Card vol. 1. New York: UNICEF; 2004.

10. Lanting CI, Fidler V, Huisman M, Touwen BC, Boersma ER: Neurological differences between 9year-old children fed breast-milk or formula-milk as babies. Lancet. 1994;344(8933):1319-22.

11. Dennis C. Breastfeeding initiation and duration: A 1990-2000 literature review. J Obstet Gynecol Neonatal Nurs. 2002;31:12-32.

12. Gartner LM, Morton J, Lawrence RA, Naylor AJ, O'Hare D, Schanler RJ, Eidelman AI. Breastfeeding and the use of human milk. Pediatrics. 2005;115(2):496-506.

13. WHO (1995) Bridging the gaps, The World Health Report 1995, Report of the Director General.

14. Government of India (2004). National Guidelines on Infant and Young Child Feeding (2004), Dept. of Women and Child Development, Government of India.

15. Philipp BL, Merewood A, O’Brien S. Physicians and breastfeeding promotion in the United States: A call for action. Pediatrics. 2001;107:584-7.

16. National Family Health Survey-4. http://rchiips.org/ nfhs/pdf/NFHS4/MP_FactSheet.pdf. 
17. Mahmood SE, Srivastava A, Shrotriya VP, Mishra P. Infant feeding practices in the rural population of north India. J Family Community Med. 2012;19(2):130-5.

18. Aruldas K, Khan ME, Hazra A. Increasing early and exclusive breastfeeding in rural Uttar Pradesh. J Family Welfare. 2010;56:43-9.

19. Pradeep C, Hemavarneshwari S. Knowledge and practice on breastfeeding and infant feeding practices in pregnant women, at Sarjapura, Bangalore. Int J Community Med Public Health. 2016 Feb;3(2):533-7.

20. Saurav C, Sandhita S. A study on KP of mothers regarding infant feeding and nutritional status of
Under 5 children attending immunization clinic of Medical college. Int J Nutr Wellness. 2008;5(1).

21. Kulkarni RN, Anjenaya S, Gujar R. Breastfeeding practices in an urban community of Kalamboli, Navi Mumbai. Indian J Community Medicine. 2004:29(4):179-80.

Cite this article as: Singh N, Chouhan Y, Trivedi A, Patel S, Sethia S. A study to evaluate breastfeeding practices among lactating mothers: a community based study in rural anganwadi centers in field practice area of government medical college, Jabalpur, Madhya Pradesh, India. Int J Community Med Public Health 2016;3:2786-93. 